\title{
SCHOOL CULTURE AND PROFESSIONAL DEVELOPMENT OF SCHOOL TEACHERS FROM URBAN AND RURAL AREAS IN CHINA
}

\author{
Zhang Ling ${ }^{1}$, Jiang $\mathrm{Na}^{1 *}$, Siaw Yan-Li ${ }^{2}$, Joko Sriyanto ${ }^{3}$ \\ ${ }^{1}$ Shangrao Normal University, China \\ ${ }^{2}$ University of Malaya, Malaysia \\ ${ }^{3}$ Universitas Negeri Yogyakarta, Indonesia \\ *e-mail:419431126@qq.com
}

\begin{abstract}
Rural teacher recruitment and retention has become a common concern globally including in China. In order to understand the underlying reasons that cause rural teachers' attrition, this study aims to explore the school culture and professional development of the teachers from urban and rural areas of China provinces, by examining three study objectives: teaching location and socio-demographic factor; challenges faced by rural teachers; and strategies to develop teaching professionalism in rural schools. A mixed-method approach involving survey forms and interview sessions was used for data collection. Data were analyzed using SPSS and ATLAS.ti which included inferential and thematic analysis. A number of 1547 teachers under Compulsory Education in Jiangxi, China were involved as participants. Results indicated that teaching location is significantly related to the socio-demographic condition. Additionally, five challenges reported by rural school teachers include parental involvement, working environment, salary, personal growth, and family environment. Meanwhile, three main strategies used for professional development are educational beliefs, collaboration relationships, and teacher self-training. The outcome of this study would contribute towards effective and feasible measures to stabilize rural teachers, promote educational and social equity, and promote the integration of urban and rural teachers. Findings conclude the importance to explore further and propose the corresponding measures to improve the working and living status of rural teachers.
\end{abstract}

Keywords: compulsory education, living and working conditions, school culture, teaching professionalism, rural and urban areas

\section{BUDAYA SEKOLAH DAN PENGEMBANGAN PROFESIONAL GURU SEKOLAH PERKOTAAN DAN PEDESAAN DI CHINA}

\begin{abstract}
Abstrak: Perekrutan dan retensi guru di sekolah pedesaan telah menjadi perhatian global, termasuk China. Penelitian ini bertujuan untuk mengeksplorasi guru perkotaan dan pedesaan dalam kaitannya dengan budaya sekolah dan pengembangan profesional dengan meneliti: lokasi kerja dan sosio-demograf; tantangan yang dihadapi oleh guru pedesaan; dan strategi untuk meningkatkan profesionalisme pengajaran di sekolah-sekolah pedesaan. Metode campuran (Mixed Method) yang melibatkan survei dan sesi wawancara digunakan untuk pengumpulan data. Penelitian ini melibatkan 1.547 guru dari sekolah jenjang Wajib Belajar di Jiangxi, China. Data dianalisis menggunakan SPSS dan ATLAS.ti, termasuk untuk analisis inferensial dan tematik. Hasil penelitian menunjukkan bahwa lokasi mengajar secara signifikan berkorelasi dengan sosio-demografi. Selain itu, lima tantangan dilaporkan oleh guru sekolah pedesaan terdiri dari: keterlibatan orang tua; lingkungan kerja; gaji; pengembangan pribadi; dan lingkungan keluarga. Sementara tiga strategi utama digunakan untuk peningkatan profesionalisme adalah: cara pandang terhadap pendidikan; hubungan kolaborasi; dan pelatihan mandiri guru. Hasil dari penelitian ini akan memberikan kontribusi terhadap langkah-langkah yang efektif dan layak untuk menstabilkan jumlah guru pedesaan, mendorong kesetaraan pendidikan dan sosial, dan mempromosikan integrasi guru perkotaan dan pedesaan. Temuan penelitian menyimpulkan bahwa penting untuk mengeksplorasi lebih lanjut dan mengusulkan langkah-langkah yang sesuai untuk meningkatkan status kerja dan kehidupan guru pedesaan.
\end{abstract}

Kata Kunci: wajib belajar, kondisi kerja dan kehidupan, budaya sekolah, profesionalisme mengajar, pedesaan dan perkotaan 


\section{INTRODUCTION}

High-quality teachers are the key element to promote quality education. Measuring educational equality has now become a consensus for scholars worldwide (Allen \& Malloy 2007; Burton, Brown, \& Johnson, 2013; Wu \& Qing, 2015). Empirical evidence shows that many nations are facing critical challenges in the recruitment and retention of rural teachers. Even in developed countries like the United States of America, the United Kingdom, Australia, and Canada, rural teacher attrition was described as a formidable problem for educational development and equality (Ingersoll, 2002; Guarino, Santibanez, \& Daley, 2006; Burton et al., 2013; Perryman \& Calvert, 2019). The issue of teacher attrition has been reported to have a negative influence on the educational quality in these countries (Allen \& Malloy 2007; Burton et al., 2013; Grimmett \& Echols, 2000). However, respectable studies regarding this issue had only been conducted in the Western context, with limited studies in developing countries due to its cultural context (Gelfand, Erez, \& Aycan, 2007). There is a need to study the scenario from developing countries to comprehensively examine the issue of rural teacher recruitment and retention, and China as a typical developing country was selected for this study.

China is an agricultural nation with the largest education scale in the world. Half of the Chinese people live in the countryside. Therefore, rural education plays a crucial role in national development. In 2019, the rural population accounts for $65 \%$ of mainland China's total population. Tabulation on the 2010 population of the People's Republic China shows there were $609,708,623$ rural residents, of which $7.25 \%(44,174,664)$ rural residents had never been to school, $38.06 \%(232,068,330)$ received primary school education, $44.90 \%$ $(273,812,219)$ received junior high or middle school education, $7.73 \%(47,099,999)$ received high school education, and only $2.06 \%$ $(12,553,411)$ received junior college education and above (The Sixth National Population Census, 2010). On the contrary, urban schools' enrollment rates to colleges and universities are much higher than rural schools. Beyond that, in the years of 2009, 2012, and 2015, students' performance of Shanghai on the PISA test was ranked the world first, which had indicated the high efficiency and quality of Shanghai teachers (Lo, 2019). Compared to Shanghai, a leading metropolis in China, in some remote rural areas in Northwest China, teachers were ill-prepared to teach and struggled to meet the elementary requirement of educational reform which was a general phenomenon (Pan, 2009; Zhou, 2012; Wang \& Li, 2017).

Educational injustice between urban and rural areas has been a persistent issue since the Chinese government implemented the "opening up" and "socialist market economy" policy (Guo, Guo, Beckett, Li, \& Guo, 2013), and continuously enlarges the gap between urban and rural areas. The issue of educational inequality has caused a massive rural teacher attrition since 1985 , especially the veteran teachers with good teaching ideas and approaches (Liu, 2012). Data show that from the year of 2010 to 2013 , the number of rural teachers nationwide fell from 4,729,500 to 3,304,500. (Miao, 2009; Fu \& Fan, 2018; Zeng \& Gao, 2018). Liu, Zhu, \& Wang (2019) conducted national research that involved 43,262 rural teachers and 3,547 rural school principals in 18 provinces (35 cities) to study on the stability mechanism of rural teachers, and found that the annual attrition rate of rural school teachers was $6.01 \%$; and $75 \%$ of the rural teachers were reported having the intention to leave their jobs. This is in line with China's rural education development report (2013-2014) in which more than $60 \%$ of rural school teachers wanted to teach in cities. The attrition of rural teachers has become a critical issue that affects the improvement of rural education quality. Consequently, low teaching quality in rural areas results in students having poorer academic performance than urban students. For this reason, the recruitment and retention of excellent teachers for rural schools have always been an imperative policy and strategic mission for the Chinese government to develop rural education.

In order to solve the problem of rural teacher attrition, the Chinese government has then successively issued a series of policies including, Special Position Program in 2006, the Free Teacher Education Program in 2007, and other preferential policies to guide and encourage outstanding teachers and graduates to teach in rural areas. Especially in 2015, the Chinese government issued a national document entitled The Support Plan for Rural Teachers 
(2015-2020) aimed to retain teachers of rural areas, to promote the flow of outstanding urban teachers to rural schools, narrow the gap between rural and urban schools, and finally promote educational equity and improve the quality of education.

Despite this, since the release of the document, numerous scholars from China had conducted research to evaluate the effectiveness of the policy. Studies had found that although these policies had a positive impact on the rural teacher team construction, an indisputable fact is that the problem of rural teachers' attrition is still very serious (Wang, Wang, Li, \& $\mathrm{Li}$, 2016). Zhang, $\mathrm{Xu}, \&$ Yue (2013) demonstrated that individuals who participate in the Free Teacher Education Program (2007) did not want to serve in rural schools after their graduation. Additionally, more than $62 \%$ of the participants in the Special Position Program (2006) intended to transfer to urban schools after the completion of their contract ( $\mathrm{Wu} \& \mathrm{Li}, 2015)$. The attrition of qualified rural teachers has always been a burning question by the Chinese government (Liu, 2012). Therefore, it is important to understand the reasons that cause rural teacher attrition.

In China, the scholars commonly acknowledge that economic factors (such as low salary, harsh living conditions); school factors (such as opportunities of academic title assessment $\square$ promotion and professional career development); social factors (such as low social status; not recognized by the society); and personal factors (such as pressure and stress) are the main reasons that cause rural teacher attrition (Liu \& Teddlie, 2010; Liu, 2012; Lv, 2019). Urban schools are generally better than rural ones in terms of overall school conditions, salary, and welfare. These were thought to be the main reason that causes teacher attrition (Shi \& Yang, 2004). According to Gong, Zhong, \& Yu (2011), the mobility intention of rural teachers was negatively correlated with their monthly income. Teachers' salary that cannot be guaranteed inevitably leads to the attrition of many excellent teachers (Pang \& Han, 2006). However, Gao (2016) pointed out that although the government has issued policies to improve the teachers' welfare, many issues emerge during the implementation process, such as the local government's lack of awareness to truly implement the policy, as well as the number of central and western areas with very weak financial capacity, which prevent them from implementing the policies optimally.

Studies discovered that most rural teachers perceived that they had a low social status (Gong et al., 2011; Zhou, 2015, Lui et al, 2019). Interestingly, Liu et al. (2019) study also found that teachers with such perception normally had a strong willingness to leave their current work. Since the 1950s, China's urban and rural areas have been widely interpreted as rich versus poor, advanced versus backward, civilized versus savage, and modern versus traditional dual values. The urban-rural dual system makes rural school teachers at a lower level in Chinese society (Miao, 2009; Zhou, 2015). Therefore, rural teachers have made unremitting efforts in order to improve their social status, including leaving the countryside and join the city. Rural teachers need more professional development opportunities than urban teachers. Nevertheless, limited opportunities are available to rural teachers which causes dissatisfaction among them (Liu et al., 2019). Lack of professional development opportunities has a negative effect on teacher's enthusiasm for work (Xing \& Miao, 2011; Yu \& Wu, 2011). Zhou (2015) explained that the lack of material support was the barrier for rural teachers to pursue their professional development. In addition to this, working condition, living condition, commuting family, and school management were other main factors that caused teacher attrition. Studies had found that the failure of the policy had directly led to insufficient investment and imbalanced resources allocation for rural education. In terms of resources, allocations such as teaching equipment, educational funds, and distributions of teachers. Ministry of Education often gives the priority to urban schools, while the vast majority of the rural areas that require support the most often claim to have received far lesser resources than the cities, which finally aggravate the urban-rural disparity (Miao, 2009; Li, 2011; Wang \& Li, 2017). As stated by Chuan (2006: 40) "For a long time, our public policies have been so city-oriented that public resources are allocated unfairly, and the majority of highquality education resources are concentrated in cities." Additionally, an irrational management system is another reason that caused rural teacher 
attrition. Some rural schools are under dual supervision by both local educational bureaus and township government, which results in rural teachers being under heavy workload (Wang \& Li, 2017; Wang, Lv, \& Yang, 2017; Yin, 2020). On the other hand, due to the small number of students in one class, teachers must teach all the subjects which lead to rural teachers being under heavy pressure of work (Yao, 2005).

Besides, the level of public services such as recreation and medical treatment in the place where they work has low quality. Gao (2011) mentioned medical treatment and social security as some of the barriers for rural teacher retention. Yu \& Wu's (2011) research also found that $78 \%$ of teachers were not satisfied with the local medical conditions. Beyond that, $23.16 \%$ and $13.01 \%$ of rural teachers claimed the accommodation conditions were poor or very poor, respectively. Meanwhile, Bai \& Fan (2013) discovered that housing issues were one of the main concerns of rural teachers. Respectively, $84.34 \%$ and $85.58 \%$ of teachers who are away from their parents and friends had a desire to leave their current schools. The fact that rural teachers' job evaluation, salary, welfare, and promotion were not determined by personal performance, but a personal relationship with school leaders, had a negative impact on teachers' enthusiasm (Yu \& Wu 2011). Furthermore, compilation deficiency was one of the biggest reasons that caused teacher attrition. As Pang \& Han (2009) pointed out, currently the implemented compilation standard shows the upside-down and unreasonable characteristics in urban and rural areas which directly increase the work intensity and burden of rural school teachers.

From outcomes of the literature reviews and problem stated, this in-depth study attempted to understand the issues of rural school teachers by focusing on the three study objectives: (1) to examine the relation between the teacher teaching location (rural and urban) with the demographic aspects of age, gender, educational level, years of services, and, spouse working status; (2) to identify the challenge faced by rural school teachers; and (3) to explore the strategy used by rural school teachers to develop their teaching professionalism.

\section{METHODS}

This present study used a mixed-method approach that involved survey forms and interview sessions for data collection. The research design of this quantitative study was a descriptive, non-experimental study that involved the systematic and detailed collection of data. A set of questionnaires was used to collect the demographic data from a pool of 1,547 teachers selected randomly from rural and urban schools in Jiangxi, China; while the interview sessions were carried out in rural schools involving six rural school teachers who volunteered to participate in this study. A pilot test was done for the interview protocol with teachers from another province to ensure the validation and reliability of the instrument. The purpose of the pilot test in the qualitative approach was to refine the interview guide. The pilot test reported a positive evaluation of the flow of the interview, as well as the language and focus of the questions. The researcher ensured that the permission was sought before data collection. The researcher explained to all respondents the purpose of the study and the confidentiality of the respondents during the questionnaire session. During the interview, the respondents were given the freedom to express their experiences, reviews, and comments to get in-depth information related to the research objectives. The identity of the respondents was anonymized by using pseudonyms. Participants consisted of 1,547 public school teachers in Jiangxi, China. Of the 1,547 teachers, 704 (45.5\%) were urban school teachers and 843 $(54.5 \%)$ were rural school teachers. Among the participants, majority are female teachers ( $n$ $=1022 ; 66 \%)$ with a degree qualification $(n=$ $1131 ; 73.1 \%)$.

Table 1 indicates the demographic data of the participants. Generally, primary data and secondary data were being used to gather information for data analysis. SPSS was used to analyze the research data which included inferential analysis for study objective 1 . Inferential analysis involved Chi-Square analysis; while, study objectives 2 and 3 acquired the ATLAS.ti program for thematic analysis. Six teachers from rural schools were involved in the face-to-face interview sessions conducted by the researcher. 
Table 1. Participants' Demographic Data

\begin{tabular}{llcc}
\hline Item & & Frequency & Percent \\
\hline Gender & Male & 525 & 33.9 \\
Age & Female & 1022 & 66.1 \\
& 20 to 30 years old & 578 & 37.4 \\
& 31 to 40 years old & 170 & 11.0 \\
Educational level & 41 to 50 years old & 402 & 26.0 \\
& 51 years old and above & 299 & 19.3 \\
& Secondary & 36 & 2.3 \\
& Junior college & 373 & 24.1 \\
Years of teaching & Degree & 1131 & 73.1 \\
& Master/PhD & 7 & .5 \\
& Less than 5 years & 499 & 32.3 \\
Spouse's working status & 291 & 18.8 \\
\multirow{5}{*}{ Training } & 5 to 10 years & 282 & 18.2 \\
& 11 to 20 years & 475 & 30.7 \\
& More than 20 years & 720 & 46.5 \\
& Employment & 827 & 53.5 \\
& Often & 420 & 27.2 \\
& Sometimes & 984 & 63.6 \\
\hline
\end{tabular}

\section{FINDINGS AND DISCUSSION}

\section{Findings}

\section{Teaching Location and Demographic Aspect}

A Chi-square test was used to examine the difference between the teaching location (rural and urban) and the demographic aspect consisting of age, gender, educational level, years of services, and spouse's working condition. Table 2 shows that there was a significant difference between the teacher teaching location (urban and rural) and the demographic aspect with the significant values less than .001 .

Table 2. The Significant Difference between Teacher Teaching Location and Demographic Aspect

\begin{tabular}{|c|c|c|c|c|}
\hline \multirow{2}{*}{ Item } & & \multicolumn{2}{|c|}{ Frequency (\%) } & \multirow{2}{*}{$x^{2}$} \\
\hline & & Urban & Rural & \\
\hline \multirow[t]{2}{*}{ Gender } & Male & $178(25.28 \%)$ & $347(41.16 \%)$ & $43.14 * * *$ \\
\hline & Female & $536(74.72 \%)$ & $496(58.84 \%)$ & \\
\hline \multirow[t]{4}{*}{ Age (years) } & 20 to 30 & $171(24.28 \%)$ & $407(48.27 \%)$ & $251.35 * * *$ \\
\hline & 31 to 40 & $123(17.47 \%)$ & $47(5.57 \%)$ & \\
\hline & 41 to 50 & $277(39.34 \%)$ & $125(14.82 \%)$ & \\
\hline & $\geq 51$ & $133(18.88 \%)$ & $264(31.30 \%)$ & \\
\hline \multirow[t]{4}{*}{ Years of teaching } & $<5$ & $137(19.46 \%)$ & $362(42.94 \%)$ & $141.78 * * *$ \\
\hline & 5 to 10 & $146(20.73 \%)$ & $145(17.20 \%)$ & \\
\hline & 11 to 20 & $200(28.40 \%)$ & $82(9.72 \%)$ & \\
\hline & $>20$ & $221(31.39 \%)$ & $254(30.13 \%)$ & \\
\hline \multirow[t]{4}{*}{ Educational level } & Secondary & $6(.85 \%)$ & $30(3.55 \%)$ & $81.38 * * *$ \\
\hline & Junior & $103(14.63 \%)$ & $270(32.02 \%)$ & \\
\hline & Degree & $591(83.94 \%)$ & $540(64.05 \%)$ & \\
\hline & Master/PhD & $4(.56 \%)$ & $3(.35 \%)$ & \\
\hline \multirow{2}{*}{ Spouse's working status } & Self-employment & $458(65.06 \%)$ & $369(43.78 \%)$ & $69.85^{* * *}$ \\
\hline & Employment & $246(34.94 \%)$ & $474(56.22 \%)$ & \\
\hline
\end{tabular}

$* * * p<.001$ 
The results presented in Table 2 indicate that there are more female teachers than male teachers in both urban and rural areas. In rural areas, the overall proportion of female teachers was $58.84 \%$, while in urban areas, female teachers take $74.72 \%$. In terms of the relationship between the teaching area and gender, the chi-square test of the cross table shows that the significant $p$-value is less than .001 , thus there are significant differences in the gender of teachers in different teaching areas. The proportion of male teachers in rural areas is significantly higher than that of male teachers in urban areas. In terms of age, Table 2 shows that there is a significant difference in teachers' age in different teaching areas. The proportion of teachers aged 30 to 40 and 40 to50 in urban areas is greater than the rural areas, while the proportion of teachers aged 20 to 30 , and 50 above is higher in the rural areas.

Based on the data, the teaching experiences of the teachers are significantly different. Teachers having five years or lower teaching experience and more than 20 years in urban areas are smaller in number than teachers in rural areas. Then, there are more teachers with teaching experience between 10 to 20 years in urban than in rural areas. The proportion of teachers with teaching experience between 5 to 10 years is similar in both urban and rural areas. In addition, there are significant differences in the working status of teachers' spouses in different teaching areas. The proportion of teachers' spouses working in cities and towns, as well as in national enterprises and institutions are higher than that of teachers working in rural areas as presented in Table 2. The proportion of teachers' spouses working in rural areas seeking jobs by themselves is higher than that of teachers working in cities and towns.

\section{Challenges for the Rural School Teachers}

The second research is formulated to explore the challenge faced by rural school teachers in China. The results of this study show that there are five most frequent challenges faced by rural school teachers, namely (1) parental involvement, (2) working environment, (3) salary, (4) personal development, and (5) family environment. Table 3 presents the challenges faced by rural school teachers and the aspect that they belong to.

Table 3. Challenges Faced by Rural School Teachers

\begin{tabular}{ll}
\hline Code & Theme \\
\hline $\begin{array}{l}\text { Parents working in town; Living with grandparents; Parents spending more time } \\
\text { to work; Students learning and living depending on teachers }\end{array}$ & Parental involvement \\
$\begin{array}{ll}\text { School facilities; Collaboration; Teaching and learning process; Workload } \\
\text { Wage gap; Gap between urban and rural areas; Low income; Burden of the }\end{array}$ & $\begin{array}{l}\text { Working environment } \\
\text { family }\end{array}$ \\
$\begin{array}{ll}\text { Promotion; Performance; Self-improvement; Knowledge and skill development } \\
\text { Spouse relation and support; Child educational development; Socio-economic }\end{array}$ & $\begin{array}{l}\text { Personal development } \\
\text { Family environment }\end{array}$ \\
\hline
\end{tabular}

\section{Strategy to Develop Teaching Professionalism}

The third research objective is to identify the strategy used by rural school teachers to develop their teaching professionalism. As presented in Table 4, the collected data show that there are three main strategies used by rural school teachers to develop their professionalism. They are (1) educational belief, (2) collaboration relationship, and (3) self-training. The findings of this study indicate that educational belief plays an important role in motivating teachers and develop their professionalism. Positive psychology, such as a change to be better, readiness to improve, and belief of success are the concepts used by rural school teachers to develop their professionalism. The teachers claim that cooperation, helping each other's and teamwork play an important role in teacher professional development. In rural areas, working alone will not make the teachers achieve educational objectives. Moreover, individual performance will develop due to limited resources and information. On the one hand, the rural school teachers inform that self-training is needed to improve their professionalism in implementing teaching strategies. They join online learning, workshops, group discussions, and do some reading. 
Table 4. Strategies to Develop Rural School Teacher Professionalism

\begin{tabular}{|c|c|c|}
\hline Teacher Statement & Code & Theme \\
\hline $\begin{array}{l}\ldots \text { strengthen our own educational beliefs } \ldots \\
\ldots \text { mentally accept and believe ... } \\
\ldots \text { ready and believe we can change students here } \ldots \\
\ldots \text { education can be achieved anywhere } . . \\
\ldots \text { we can do that ... }\end{array}$ & $\begin{array}{l}\text { Belief } \\
\text { Readiness } \\
\text { Change }\end{array}$ & Educational belief \\
\hline $\begin{array}{l}\ldots \text { helping each other ... } \\
\ldots \text { together carrying out activities for students ... } \\
\ldots \text { school professional community ... } \\
\ldots \text { cooperate and learn from each other } \ldots \\
\ldots \text { discussion and open dialogues } \ldots\end{array}$ & $\begin{array}{l}\text { Cooperation } \\
\text { Helping } \\
\text { Teamwork }\end{array}$ & Collaboration relationship \\
\hline $\begin{array}{l}\ldots \text { we use online learning ... } \\
\ldots \text { through the internet after school ... } \\
\ldots \text { school invites experts to conduct workshop ... } \\
\ldots \text { read more and exchange ideas, discussion ... }\end{array}$ & $\begin{array}{l}\text { Self-learning } \\
\text { Workshop } \\
\text { Discussion } \\
\text { Reading }\end{array}$ & Self-training \\
\hline
\end{tabular}

\section{Discussion}

Demographic variables have huge impacts on teacher teaching location either in urban or rural areas. The findings of this present study indicate that there are differences between the locations (urban vs rural) of the teachers and other aspects, namely gender, age, year of teaching, educational level, and spouse's working status. This result is in line with a study by Guarino et al. (2016) and Allensworth, Ponisciak, \& Mazzeo (2009) showing that teacher demographic variables have a significant influence on teacher attrition and turnover intension such as age and year of teaching. According to Feng (2017), most of the rural school teachers are middle-aged and elderly with more traditional education concepts and teaching-style compare to urban school teachers. Statistics show that since 2011, the growth rate of rural teachers has lagged far behind the vigorous development of rural education (Lasalvia \& Tansella, 2011). In addition, rural primary and secondary schools tend to have more teachers at the age of over 50 as those between 30 to 40 years old tend to migrate to cities and towns searching for a better life.

Previous studies indicate that rural teachers in China are working under immense work pressure, which greatly affects their mental health and causes an unsatisfying working environment (Meng \& Liu, 2008; Li, 2020). They not only need to teach students basic science and professional skills but also take care of their students after school due to a lack of parental commitment and involvement in education. This is somehow similar to the findings of this study. Rural school teachers claim that there are a lot of challenges, such as parental involvement, working environment, and family environment (Wu \& Tian's, 2019; Yin, 2020). According to Li (2020), personal development and family pressure are two important indicators of work stress. Work stress greatly affects individual mental health and job burnout (Dreison, Luther, Bonfils, Sliter, McGrew, \& Salyers, 2016). At present, how to develop teacher teams and help them relieve work pressure as well as improve the quality of rural education has become a new challenge for school management teams (White, Aalsma, Holloway, Adams, \& Salyers, 2015).

According to Zhou \& Yuan (2010), teachers' social status is mainly composed of economic status, political status, and cultural status. From the perspective of economic status, most studies point out that salary is an important factor affecting the attrition of rural teachers. Meng \& Liu (2008) state that compared to rural teachers, urban teachers are more likely to have better compensation. Moreover, urban teachers have more sources of income due to the fact that urban parents tend to support their children for after school classes. This makes a significant difference between urban and rural teachers (Liu, 2012). This is consistent with findings revealed by Zhao \& Qin (2016) that the lower the salary income, the stronger their willingness to flow. However, several studies present that non-monetary factors like working 
environment, emotional needs, and self-worth recognition might be more important than salary and welfare (Hanushek \& Welch, 2006). Most of the existing studies are based on neoclassical economic theory and take the rational man and utility maximization as the basic assumption. However, in order to verify the assumptions more empirical studies are needed.

From the perspective of political status, the social capital of rural teachers is deeply influenced by the dual social structure. For a long time, China has pursued the policy of giving priority to the development of cities and supporting the development of cities by rural areas. This unbalanced supply of social resources and somehow discriminating policies have directly caused the low status of rural teachers (Wu \& Qing, 2015; Zhao \& Liu, 2019).

From the perspective of cultural status, the change of rural social structure leads to the decline of the ethos of respecting teachers and valuing education in rural areas. Individuals' income, power, and authority become the basis for people to examine and measure the social status of rural teachers (Zhou, 2016). However, the status of rural teachers lags far behind that of the powerful departments and professional groups in society (Zhao \& Liu, 2019). Affected by this cultural status, rural teachers and even the entire rural education are underprivileged.

Teacher professionalism is the main factor that restricted the development of education. Paying attention to the professional development of rural teachers, meeting the needs of the professional development of rural teachers, and improving the rural teacher professionalism was of great significance to improve the level of basic education in rural areas and achieving a balanced development of education (Hobbs, 2017; Darling-Hammond, Hyler, \& Gardner, 2017). However, Burton, Brown, and Johnson's study in 2013 found that rural teachers are professionally isolated, lack of professional knowledge, and lack of teaching credentials. The professional development of teachers in rural areas restricts the development of rural education in China. In view of the professional development dilemma of teachers in rural weak schools, the professional development of teachers in rural schools has emerged from the predicament by strengthening teachers' educational beliefs, strengthening teachers' cooperative relations within schools, improving teachers' professional education models, and improving social support systems.

Correcting the mentality of the school and strengthening the educational beliefs of teachers in rural weak schools are very important to sustain teachers in rural area passion and performance in teaching and learning. Regardless of the conditions of schools and rural areas, the learning situation of students, and the treatment of teachers, teachers must strengthen their own educational beliefs. In addition, strengthen the cooperation of teachers with each other is important for the purpose to learn and assist each other through a professional community Zhou (2015).

To develop teacher professionalism, internal factor plays an important role. In addition to a series of theoretical training such as daily teaching theories and methods, the schools need to raise teacher reading awareness by making reading an urgent need and daily habit. Facing the complex and ever-changing social environment, the internet has become mainstream in society. Schools should focus on social integration by establishing a campus network and allowing teachers to use the network for education and teaching exchanges. By doing so, teachers can upload their educational and teaching information resources to the school resource centre for everyone to use. At the same time, they may download educational and teaching information online and make full use of network resources (Wang et al., 2016).

Nevertheless, schools are required to invite experts from all levels such as high performing teachers, teaching researchers to the school to conduct on-site lectures and guidance, such as teaching strategies, class activities, etc. This will provide a platform for all teachers to ask questions and discuss the methods to solve problems in teaching practice and enhance professional ability. To achieve an overall improvement in teacher professionalization, schools should create a good teaching and research atmosphere and make a motivated team of teachers.

\section{CONCLUSION}

This research shows striking disparities between urban and rural public teachers regarding their working and living conditions. Rural teachers are at a disadvantage compare 
to urban teachers. Furthermore, rural teachers face more challenges regarding their working and living conditions. This finding is supported by a wide array of studies conducted by Shi \& Yang, 2004; Xie, Ma, \& Yang, 2012; Wang et al., 2016. Moreover, this study finds that challenges faced by rural teachers are related to parental involvement, working environment, salary, personal growth, and family environment. Rural teachers want to pursue convenient living conditions, better treatment, and more career development opportunities. In addition, their expectations cannot be met by working as a rural teacher (Liu et al., 2019). Furthermore, family factors and children's education are the main concern for rural teachers. Male primary school teachers in rural schools find it difficult to get married, and they have a lack of career development opportunities. Rural teachers are at a social disadvantage, and this leads to the gradual attrition of young male teachers. Therefore, in order to motivate teachers to retain in rural schools, the Chinese government needs to establish related policies or mechanisms to encourage and motivate teachers to teach in rural schools such as by giving incentives. Wu \& Tian's (2019) research points out that the lack of effective incentive mechanisms results in rural teachers' lack of motivation to stay in rural schools. Then, it is found that those teachers need mental rewards more than material rewards.

The outcome of this present study can be used by policymakers in handling the gap between teaching policies in rural and urban areas and provide clear views on the problems faced by rural area teachers. This is important to improve the quality of education in rural areas to ensure every student has a right to receive quality education for their future and country development.

\section{ACKNOWLEDGEMENT}

This work was supported by China National Program-the 13th five-year plan for national education science: rural school development research [grant number: BHA170138].

\section{REFERENCES}

Allen, T., \& Malloy, W. W. (2007). Teacher retention in a teacher resiliency-building rural school. The Rural Educator, 28(2), 19-27. https://doi.org/10.35608/ruraled. v28i2.482.

Allensworth, E., Ponisciak, S., \& Mazzeo, C. (2009). The school teachers leave: Teacher mobility in Chicago public schools. Chicago, IL: Consortium on Chicago School Research. http://ccsr. uchicago.edu/content/publications.

Bai, Z. F., \& Fan, X. Z. (2013). Study on primary school teachers' housing problems in remote areas. Journal of Primary and Secondary School Principals, 9, 16-19. (in Chinese).

Burton, M., Brown, K., \& Johnson, A. (2013). Storylines about rural teachers in the United States: A narrative analysis of the literature. Journal of Research in Rural Education, 28(12), 1-18. https://jrre.psu. $\mathrm{edu} / \mathrm{sites} /$ default/files/2019-08/28-12.pdf.

Chuan, B. (2006). Policies for compulsory education disparity between urban and rural areas in China. Frontiers of Education in China, 1(1), 40-55. https:// doi.org/10.1007/s11516-005-0003-y.

Darling-Hammond, L., Hyler, M. E., \& Gardner, M. (2017). Effective teacher professional development. PaloAlto, CA: Learning Policy Institute. https:// learningpolicyinstitute.org.

Dreison, K. C., Luther, L., Bonfils, K. A., Sliter, M. T., McGrew, J. H., \& Salyers, M. P. (2016). Job burnout in mental health providers: a meta-analysis of 35 years of intervention research. Journal of Occupational Health Psychology, 23(1), 18. https://doi.org/10.1037/ocp0000047.

Hobbs, R. (2017). Approaches to teacher professional development in digital media literacy education. In B. De Abreu, P. Mihailidis, A. Lee, J. Melki, \& J. McDougall (Eds). International handbook of media literacy education. New York, NY: Routledge, pp. 88-113. https://doi. org/10.4324/9781315628110.ch5.

Fu, W. D. \& Fan, X. Z. (2018). On the supporting Project of Rural Teachers (2015-2020): Effect, problems, and countermeasures. 
Journal of Central China Normal University (Humanities and Social Sciences), 57(1), 163-173. (in Chinese).

Gao, J. W. (2016). Attrition of backbone teachers in rural schools and corresponding strategies. Journal of Teaching and Management, 22, 21-23. (in Chinese).

Gelfand, M., Erez, M., \& Aycan, Z. (2007). Cross-cultural organizational behavior. Annual Review of Psychology, 58(1), 479-514. https://doi.org/10.1146/annurev. psych.58.110405.085559.

Grimmett, P., \& Echols, F. (2000). Teacher and administrator shortages in changing times. Canadian Journal of Education/Revue Canadienne De L'éducation, 25(4), 328-343. https://doi. org/10.2307/1585854.

Guarino, C. M., Santibañez, L., \& Daley, G. A. (2006). Teacher recruitment and retention: A review of recent empirical literature. Review of Educational Research, 76(2), 173-208. https://doi. org/10.3102/00346543076002173.

Guo, S. B., Guo, Y., Beckett, G., Li, Q., \& Guo, L. Y. (2013). Changes in Chinese education under globalization and market economy: Emerging issues and debates. Compare: $A$ Journal of Comparative and International Education, 43(2), 244-264. https://doi.org /10.1080/03057925.2012.721524.

Hanushek, E. A., \& Welch, F. (2006). Handbook of the Economics of Education ( $\mathrm{vol} 2$ ). St. Louis: 1sevier.

Ingersoll, R. M. (2002). The teacher shortage: a case of wrong diagnosis and wrong prescription. NASSP Bulletin, 86(631), 16-30. https://doi. org/10.1177/019263650208663103.

Lasalvia, A., \& Tansella, M. (2011). Occupational stress and job burnout in mental health. Epidemiology and Psychiatric Sciences, 20(4), 279-285. https://doi.org/10.1017/ S2045796011000576.

Li, M. (2011). Discussion and reflection on the system drawbacks of urban and rural. Education Equity, 12, 117-120. (in Chinese).

Li, S. L. (2020). Correlation among mental health, work stress and job burnour of rural teachers. Revista Argentina de Clínica Psicológica, 2020(1), 1345-1350. https://doi.org/10.24205/03276716.2020. 194.

Liu, S. (2012). The influences of school climate and teacher compensation on teachers' turnover intention in China. Educational Psychology: An International Journal of Experimental Educational Psychology, 32(5), 553-569.https://doi.org/10.1080/01 443410.2012 .691074 .

Liu, S., \& Teddlie, C. (2010). Differences in perceptions of effective school processes in differentially effective schools in China. International Journal of Management in Education, 4(3), 348-368. https://doi. org/10.1504/IJMIE.2010.033466.

Liu, S. H., Zhu, X. H., \& Wang, S. (2019). Study on the stability mechanism of rural teachers. Journal of Northeast Normal University (Philosophy and Social Science), 4, 122-127. (in Chinese).

Lo, L. N. K. (2019). Teacher and teaching in China: a critical reflection. Teachers and Teaching, 25(5), 553-573. https://doi.org/ 10.1080/13540602.2019.1632823.

Lv, T. (2019). From the cultural dimension to study on the issue of rural teacher turnover. Journal of Teaching and Management, 32, 6-8.

Meng, L., \& Liu, S. (2008). Mathematics teacher stress in Chinese secondary schools. Journal of Educational Enquiry, 8(1), 73-96. https://ojs.unisa.edu.au/index.php/ EDEQ/article/view/485.

Pan, L. (2009). The existent problem of minority compulsory education and countermeasures in the western poor region. Social Scientist, 146(6), 65-7.

Pang, L. J. \& Han, X. Y. (2006). Problems and 
countermeasures on rural compulsory educational teachers' team in China. Educational Research, 27(9), 47-53. https://www.fed.cuhk.edu.hk/ceric/ er/200600270009/0047.htm.

Pang, L. J. \& Han, X. Y. (2006). Construction of rural teachers at compulsory education stage in China: Problems and solutions. Journal of Educational Research, 9, 4753. (in Chinese).

Perryman, J. \& Calvert, G. (2019). What motivates people to teach, and why do they leave? Accountability, performativity and teacher retention. British Journal of Educational Studies, 68(1), 3-23. https:// doi.org/10.1080/00071005.2019.158941 7.

Shi, C. Y. \& Yang, Y. X. (2004). Study on the outflow of primary and secondary school teachers in economic less-developed region. Journal of Teaching and Management, 36, 17-18.

The Sixth National Population Census 2010. http://www.stats.gov.cn/tjsj/pcsj/rkpc/6rp/ indexch.htm.

Wang, Y. L. \& Li, H. Q. (2017). An empirical analysis of rural teachers' intention of Turnover: Based on the survey in Yunnan Province. Journal of East China Normal University, 35(3), 134-141. https://doi.org/10.16382/j.cnki.10005560.2017.03.014. (in Chinese).

Wang, D., Wang, J. Y., Li, H., \& Li, L. (2016). School context and instructional capacity: A comparative study of professional learning communities in rural and urban schools in China. International Journal of Educational Development. 52, 1-9. https:// doi.org/10.1016/j.ijedudev.2016.10.009.
White, L. M., Aalsma, M. C., Holloway, E. D., Adams, E. L., \& Salyers, M. P. (2015). Job-related burnout among juvenile probation officers: implications for mental health stigma and competency.

Wu, Y. L. \& Tian, C. (2019). Research on the construction of incentive mechanism for rural teachers based on ERG Theory. Higher Education Forum, 8, 62-66. (in Chinese).

Xie, G. M., Ma, Q. \& Yang, W. F. (2012). The status quo and countermeasures of balanced development of urban and rural teachers at compulsory education stage in provinces. Theory and Practice of Education, 32(20), 12-14.

Yu, L. L. \& Wu, Z. H. (2011). The investigation on the status quo and reasons of rural teacher attrition at compulsory education stage: Based on two counties from Liaoning Province. Educational Measurement and Evaluation, 6, 22-25. (in Chinese).

Zhao, K. Y. \& Liu, S. H. (2019). Research on the construction of rural teachers since the reform and opening up. Theory Monthly, 1, 154-160. (in Chinese).

Zhao, Z. P. \& Qin, Y. Y. (2016). Who is prone to turn over? An empirical study on the opportunity cost and the turnover intention of teachers in compulsory education. Education and Economics, (1), 53-62. (in Chinese).

Zhou, Y. S. (2012). A brief report of bilingual education for the Dongxiangs: A new initiative. In G. H. Beckett \& G. Postiglione (Eds.). China's assimilationist language policy: Impact on indigenous minority literacy and social harmony. London: Routledge, pp. 75-83. 